\title{
Uji pelepasan ion nikel dan kromium pada beberapa braket stainless steel yang direndam di air laut
}

\author{
${ }^{1}$ Cliff G. Lombo \\ ${ }^{2}$ P. S. Anindita \\ ${ }^{2}$ Juliatri \\ ${ }^{1}$ Kandidat Skripsi Program Studi Pendidikan Dokter Gigi Fakultas Kedokteran \\ ${ }^{2}$ Program Studi Kedokteran Gigi Fakultas Kedokteran \\ Universitas Sam Ratulangi Manado \\ Email: clifflombo@gmail.com
}

\begin{abstract}
Orthodontics is the branch of dentistry that studies about how to prevent, protect, and care of malocclusion involving teeth, as well as skeletal and soft tissues of dentofacial region. Fixed orthodontic appliance is one of the means used to achieve the treatment goal. The use of orthodontic bracket is one of the main components in fixed orthodontic treatment which serves to deliver the required force on the teeth. This study aimed to determine the amount of $\mathrm{Cr}$ and $\mathrm{Ni}$ ions released from the stainless steel bracket (brand A, B, and C) immersed in sea water. This was a laboratory experimental study with a pre-experimental and nonequivalent control group designs. Samples were assayed using UV-Vis spectroscopy to determine the release of the metals: nickel and chromium. The samples consisted of 4 kinds of brand bracket immersed in sea water for 48 hours at a temperature of $37^{\circ} \mathrm{C}$. The results showed that the release of nickel and chromium ions in sea water varied in each sample. In sample A, the release of nickel $0.096 \mathrm{ppm}$ and of chromium $0.202 \mathrm{ppm}$. In sample B, the release of nickel $0.154 \mathrm{ppm}$ and of chromium 0.027 and. In sample C, the release of nickel 0,066 ppm and of chromium 0,019 ppm. The release of chromium in each sample was higher than the release of nickel. The results showed that there was no particular pattern of the released ions. This might be due to the different composition of the stainless steel brackets depending on the terms of each manufacturer.
\end{abstract}

Keywords: bracket stainless steel, nickel and chromium, UV-Vis spectroscopy, seawater

\begin{abstract}
Abstrak: Ortodonsia adalah cabang dari ilmu kedokteran gigi yang mempelajari tentang cara mencegah, melindungi, dan merawat maloklusi yang melibatkan gigi geligi, skeletal, dan jaringan lunak regio dentofasial. Alat ortodontik cekat merupakan salah satu cara yang digunakan untuk mencapai tujuan perawatan ontodontik. Penggunaan braket ortodonti merupakan salah satu komponen utama dalam perawatan ortodonti cekat yang berfungsi untuk menghantarkan gaya yang diperlukan pada gigi. Penelitian ini bertujuan untuk mengetahui besarnya ion $\mathrm{Cr}$ dan $\mathrm{Ni}$ yang terlepas pada braket stainless steel merek A, B, dan C yang direndam dalam air laut. Jenis penelitian yang digunakan ialah eksperimental laboratorik dengan rancangan pra eksperimental serta desain penelitian nonequivalent control group. Sampel diuji menggunakan spektroskopi UVVis untuk mengetahui pelepasan logam nikel dan cromium. Sampel terdiri dari 4 macam merek braket direndam dalam air laut selama 48 jam pada suhu $37^{\circ} \mathrm{C}$. Hasil penelitian menunjukkan terdapat pelepasan logam nikel dan kromium dalam air laut yang bervariasi di tiap sampel. Sampel A memiliki pelepasan nikel 0,096 ppm dan kromium 0,202 ppm; sampel B memiliki pelepasan nikel 0,154 ppm dan kromium 0,027; sampel C memiliki pelepasan nikel 0,066 ppm dan kromium 0,019 ppm. Pelepasan kromium pada tiap sampel lebih tinggi dibandingkan dengan pelepasan nikel. Hasil penelitian tidak menunjukan pola tertentu. Hal ini dapat disebabkan karena komposisi yang berbeda-beda dari braket stainless steel tergantung ketentuan masing-masing pembuatnya.
\end{abstract}

Kata kunci: braket stainless steel, nikel dan cromium, spektroskopi UV-Vis, air laut 
Ortodonsia adalah cabang dari ilmu kedokteran gigi yang mempelajari tentang cara mencegah, melindungi, dan merawat maloklusi yang melibatkan gigi geligi, skeletal, dan jaringan lunak regio dentofasial. Maloklusi dapat terjadi pada semua usia dan dampak yang terjadi adalah gangguan fungsi dan estetik pada gigi. ${ }^{1}$ Berdasarkan laporan hasil Riset Kesehatan Dasar (Riskesdas) Nasional tahun 2013, sebanyak 14 Provinsi mengalami masalah gigi dan mulut yaitu $25,9 \% .^{2}$ Prevalensi maloklusi di Indonesia masih sangat tinggi sekitar $80 \%$ dari jumlah penduduk, dan merupakan salah satu masalah kesehatan gigi dan mulut yang cukup besar. Hal ini ditambah dengan tingkat kesadaran perawatan gigi yang masih rendah dan kebiasaan buruk seperti menghisap ibu jari atau benda-benda lain. Jumlah dan keparahan maloklusi akan terus meningkat maka maloklusi seharusnya dicegah ataupun ditangani. ${ }^{3}$

Alat ortodontik cekat merupakan salah satu cara yang digunakan untuk mencapai tujuan perawatan ontodontik. Braket ortodonti merupakan salah satu komponen utama dalam perawatan ortodonti cekat yang berfungsi untuk menghantarkan gaya yang diperlukan pada gigi, oleh karena itu braket yang digunakan harus diproduksi dengan akurat, baik dari segi bentuk, tingkat kekuatan maupun tingkat ketahanan korosi serta biokompabilitas. ${ }^{4}$

Komposisi yang terkandung di dalam braket ortodontik stainless steel adalah $71 \%$ ferrum atau besi karbon (Fe), 18\% cromium (Cr), 8\% nikel (Ni) dan 0.2\% karbon (C). ${ }^{5}$ Penambahan Fe dalam kawat ortodontik stainless steel ini cenderung bukan sebagai alasan untuk ketahanan korosi tetapi sebagai alasan ekonomis, karena Fe merupakan salah satu unsur yang banyak dijumpai dan ditemukan di dalam kehidupan sehari-hari sehingga banyak digunakan dalam campuran logam. Unsur $\mathrm{Cr}$ berguna untuk menambah ketahanan braket ortodontik stainless steel terhadap korosi. Unsur lainnya yaitu $\mathrm{Ni}$ yang memberikan sifat baik pada braket untuk formabilitas, kekerasan, dan tahan terhadap panas. Kelemahan dari unsur $\mathrm{Ni}$ dan $\mathrm{Cr}$ adalah dapat menyebabkan alergi apabila terlepas dalam rongga mulut. ${ }^{1,5}$ Braket logam yang dipakai umumnya dari

bahan baja nirkarat, bahan ini mengandung nikel yang dapat bersifat sebagai alergen. Reaksi alergi yang dilaporkan berfariasi yaitu edema lidah, mouth lining sampai anafilaksis. $^{6}$

Potensi logam menyebabkan reaksi alergi berhubungan dengan pola dan modus korosi, yang diikuti pelepasan ion-ion logam seperti nikel ke dalam rongga mulut. Hal ini tidak hanya tergantung pada komposisi logam tetapi juga suhu dan $\mathrm{pH}$ lingkungan. Dapat kita ketahui daerah Sulawesi Utara banyak sekali terdapat pantai yang merupakan objek wisata bahari di Indonesia. Kegiatan berenang di pantai dicurigai dapat menyebabkan korosi pada braket stainless steel bagi masyarakat yang melakukan perawatan ortodontik. Hal ini diakibatkan oleh kandungan garam yang terkandung dalam air laut yang mempunyai sifat korosif terhadap logam. Bahan stainless steel bila sering terpapar ion natrium dan klorida yang terkandung pada air laut, dapat menjadi sumber kerusakan material. $^{7}$ Penelitian sebelumnya yang dilakukan oleh Aryani 2012 Jakarta terhadap perendaman ke dalam saliva buatan, menyatakan bahwa terdapat perbedaan pelepasan ion $\mathrm{Ni}$ dan $\mathrm{Cr}$ pada setiap merek braket. ${ }^{8}$

Saat ini di Indonesia telah beredar berbagai macam merek braket logam stainless steel. Namun sangat disayangkan tidak semua jenis merek braket stainless steel yang beredar di Indonesia menyertakan kandungan jenis logam yang ada pada braket tersebut dan tidak semua braket logam stainless steel telah teruji tingkat ketahanan terhadap korosi. Hal ini juga diperburuk dengan tidak adanya sistem pengujian dari pihak pemerintah Indonesia pada braket yang diimpor dari luar negeri.

Berdasarkan hal tersebut di atas penulis terdorong untuk melakukan penelitian mengenai tingkat ketahanan korosi beberapa merek braket logam 
stainless steel yang beredar di Indonesia. Penelitian ini bertujuan untuk mengetahui besarnya ion $\mathrm{Cr}$ dan $\mathrm{Ni}$ yang terlepas pada braket stainless steel merek A, B, C yang direndam dalam air laut

\section{METODE PENELITIAN}

Jenis penelitian yang digunakan adalah eksperimental laboratorik dengan rancangan pra eksperimental dan nonequivalent control group design. Penelitian ini dilakukan di Laboratorium Biokimia Jurusan Gizi Politeknik Kesehatan Kemenkes Manado, pada bulan Oktober 2015. Pemilihan 3 jenis merek braket dilanjutkan dengan melakukan pengelompokan masing-masing sampel menjadi 3 merek A,B,C yang masingmasing terdiri dari 20 buah (1 set / rahang). Melakukan sterilisasi alat menggunakan autoclave dengan suhu $121^{\circ} \mathrm{C}$ selama 15 menit.

Sebelum melakukan perendaman di dalam air laut, terlebih dahulu dihitung kadar $\mathrm{Na}$ dan $\mathrm{Cl}$ pada air laut menggunakan alat UV-Vis. Melakukan pengukuran berat braket menggunakan timbangan digital untuk menentukan banyaknya cairan perendaman dengan perbandingan $1 \mathrm{ml}$ air laut setiap 0,2 $\mathrm{g}$ berat braket. Braket stainless steel direndam menggunakan masing-masing tabung durlham yang telah diberi label sebagai penanda, kemudian ditutup rapat, selanjutnya dilakukan penyimpanan di inkubator pada temperatur $37^{\circ} \mathrm{C}$ selama 48 jam. Waktu 48 jam yang digunakan dalam penelitian ini didapatkan dari perhitungan waktu berenang di pantai yaitu 1 jam, frekuensi berenang di pantai yaitu 1 kali dalam seminggu yang dalam sebulan terdapat 4 minggu dan rata-rata minimal waktu perawatan ortodontik yaitu 1 tahun. Sehingga diperoleh perhitungan sebagai berikut : $1($ jam $) \times 1$ (frekuensi) $\times 4$ $($ minggu $) \times 12($ bulan $)=48$ jam .

Setelah dilakukan perendaman selama 48 jam, braket stainless steel dilanjutkan dengan melakukan analisis terhadap lepasan ion logam yang ditentukan, dalam hal ini yaitu ion Ni dan Cr. Pada saat melakukan analisis, ditambahkan larutan difenilkarbazida $1 \%$ untuk mendeteksi $\mathrm{Cr}$ sedangkan untuk mendeteksi $\mathrm{Ni}$ ditambahkan larutan dimetilglikosim 1\%. Lepasan logam nikel dan cromium dari braket stainless steel yang direndam di dalam air laut diukur menggunakan spektroskopi UV-Vis, dengan satuan pengukuran ppm (part per million).

\section{HASIL PENELITIAN}

Hasil pengukuran kadar $\mathrm{Na}$ dan $\mathrm{Cl}$ pada air laut sebelum dilakukan perendaman braket stainless steel.

Tabel 1. Hasil pengukuran ion $\mathrm{Na}$ dan $\mathrm{Cl}$ pada sampel air laut sebelum perendaman braket

\begin{tabular}{cc}
\hline Ion & Jumlah (ppm) \\
\hline $\mathrm{Na}$ & 0,032 \\
$\mathrm{Cl}$ & 4,282 \\
\hline
\end{tabular}

Hasil pengukuran pelepasan ion nikel dalam air laut setelah perendaman selama 48 jam menunjukkan terdapat pelepasan ion nikel yang bervariasi pada masingmasing sampel braket Gambar 1.

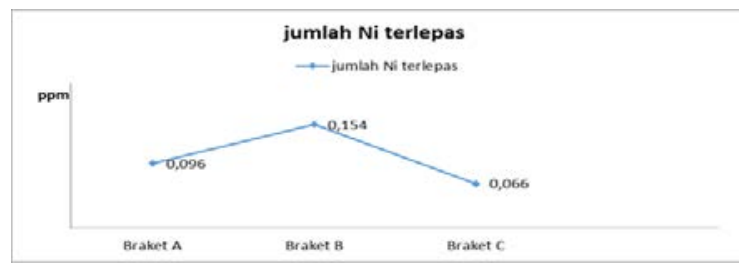

Gambar 1. Hasil pengukuran pelepasan ion nikel pada sampel A, B, C setelah perendaman di dalam air laut

Ion nikel yang terlepas dalam air laut setelah perendaman selama 48 jam paling banyak pada sampel B yaitu 0,154 ppm.

Hasil pengukuran pelepasan ion kromium dalam air laut setelah perendaman selama 48 jam menunjukkan terdapat pelepasan yang bervariasi pada masingmasing sampel braket, paling banyak pada sampel A (Gambar 2) yaitu 0,202 ppm. 


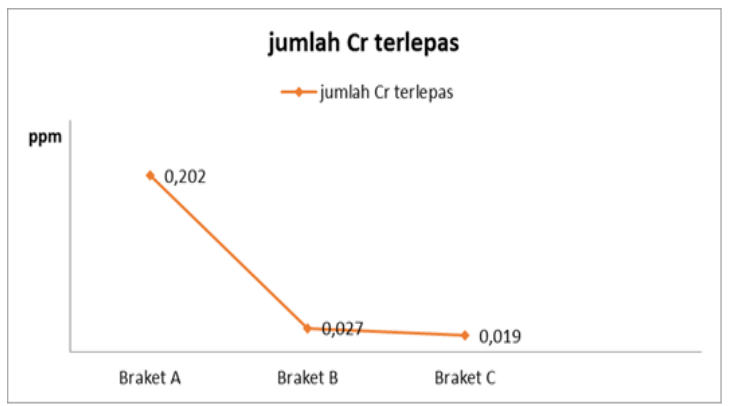

Gambar 2. Hasil pengukuran pelepasan ion cromium pada sampel A, B, C setelah perendaman di dalam air laut

\section{BAHASAN}

Hasil penelitian menunjukan terjadi pelepasan ion nikel dan kromium pada perendaman di dalam air laut. Hal ini disebabkan air laut umumnya mengandung 3,5 \% garam-garam, sedangkan garam utamanya adalah klorida (55\%), natrium (31\%), sulfat (8\%), magnesium (4\%), kalsium (1\%), potasium (1\%) dan sisanya (kurang dari 1\%) terdiri dari bikarbonat, bromida, asam borak, strontium dan florida. ${ }^{9}$ Ion klorida termasuk ion agresif yang dapat menyerang lapisan pasif baja dan meningkatkan laju korosi. Korosi logam pada air laut mengikuti mekanisme pada elektrokimia karena pada logam yang mengalami korosi terdapat tempat-tempat berupa anoda dan katoda. ${ }^{10}$ Salah satu jenis korosi yang sering terjadi ketika baja berada di lingkungan air laut adalah korosi sumuran. Penelitian menyatakan bahwa salah satu penyebab terjadinya korosi sumuran adalah ion-ion $\mathrm{Cl}^{10}$ Selain ion $\mathrm{Cl}$, kadar natrium yang melebihi $100 \mathrm{mg} / \mathrm{L}$ kurang baik bagi kepentingan industri karena dapat membentuk karat dan menyebabkan terjadinya korosi pada peralatan logam. ${ }^{11}$

Hasil pengukuran menunjukkan bervariasinya pelepasan ion nikel dan cromium. Pelepasan terbesar cromium terdapat pada sampel A sedangkan pelepasan terbesar nikel terdapat pada sampel B. Hal ini dapat disebabkan oleh komposisi ketiga braket stainless steel bervariasi baik dari nikel dan cromium. Keadaan ini berkaitan dengan klasifikasi menurut AISI, AISI mengklasifikasikan sebagian besar alat ortodonti yang terbuat dari stainless steel merupakan golongan austenistik tipe 304 SS dengan kandungan 18-20\% cromium, 8-10\% nikel serta sedikit campuran mangan dan silikon, dan kurang dari $0,03 \%$ karbon. $^{4,12}$

Kromium dapat membentuk lapisan tipis film kromium oksida $\left(\mathrm{CR}_{2} \mathrm{O}_{3}\right)$ atau yang disebut dengan passive surface oxide di atas permukaan logam dan bersifat self repairing oxide di atas permukaan logam. Nikel dapat menambah kekerasan, ketahanan terhadap panas dan memberikan kelenturan pada braket. ${ }^{4,1} \mathrm{Hal}$ ini dapat memengaruhi harga dari braket stainless steel yang beredar di pasaran. Harga yang ekonomis kemungkinan disebabkan oleh sedikitnya campuran logam nikel dan cromium dalam komposisi yang sebenarnya merupakan komponen yang penting dalam sebuah braket stainless steel.

Berdasarkan hasil penelitian, pelepasan ion nikel dan cromium pada masing-masing sampel tidak memiliki perbandingan maupun pola tertentu. Sampel A memiliki pelepasan cromium paling banyak dibandingkan sampel lainnya namun pelepasan nikelnya terbanyak kedua setelah sampel B dan sampel C. Sampel B memiliki pelepasan nikel paling banyak dibandingkan dengan sampel A dan sampel C. Minano et al menyarankan para ortodontis untuk menggunakan braket logam stainless steel dengan tingkat ketahanan korosi yang paling baik, sehingga jumlah ion terlepas yang dapat memengaruhi kesehatan umum menjadi minimal. ${ }^{12}$ Pemakaian braket dengan pelepasan nikel dan kromium yang berlebihan dalam jangka waktu yang lama dapat memengaruhi kesehatan tubuh karena termasuk kelompok logam berat yang dapat menyebabkan reaksi hipersensitivitas tipe IV. ${ }^{10}$ Pelepasan ion nikel dan cromium serta dampaknya bagi tubuh masih membutuhkan penelitian lebih lanjut, karena komposisi dan cara pembuatan produk stainless steel merupakan rahasia dari masing-masing perusahaan pembuatnya. 


\section{SIMPULAN}

Hasil penelitian ini menunjukkan bervariasinya ion nikel dan cromium yang terlepas dari kelompok braket, A, B, dan C. Pelepasan ion nikel pada braket A 0,096 ppm, braket B 0,154 ppm, dan braket C 0,066 ppm, dan untuk pelepasan cromium pada braket A 0,202 ppm, braket B 0,027 ppm, dan braket C 0,019 ppm.

\section{SARAN}

1. Melakukan penelitian yang serupa dengan jenis produk lain yang lebih bervariasi, serta perlu dilakukan penelitian lebih lanjut mengenai efek perendaman di dalam air laut pada braket staainless steel dalam jangka waktu yang berbeda.

2. Menyarankan pada pihak yang terkait untuk melakukan uji korosi pada braket logam stainless steel ortodonti yang beredar di Indonesia seperti yang dilakukan pada alat kesehatan lainnya

\section{DAFTAR PUSTAKA}

1. Bishara SE. Textbook of Orthodontics. United States of America: W.B Saunders Company, 2001; p. 60-7.

2. Badan Penelitian dan Pengembangan Kesehatan. Departemen Kesehatan RI. Laporan hasil riset kesehatan dasar (Riskesdas) Nasional 2013. Jakarta, 2013; p.111-2.

3. Laguhi VA, Anindita PS, Gunawan PN. Gambaran Maloklusi Dengan Menggunakan HMAR Pada Pasien di Rumah Sakit Gigi dan Mulut Universitas Sam Ratulangi Manado. eGiGI. 2014;2(2);1-7.
4. Oh KT, Choo SU, Kim KM, Kim KN. A Stainless steel Bracket for Orthodontic Application. Eur J Orthod. 2005;27:237-44.

5. Shreir LL, Jarman RA, Burstein GT. Corrosion Metal/Environment Reaction. Britain: Butterworth Heinemann, 2000; p. 245-50.

6. Kusy RP. The future of orthodontic materials: the long term view. Am J Orhod Dentofac Orthop. 1998;113; 91-5.

7. Siagian FR, Sulistijono, Susanti D. Pengaruh Variasi Konsentrasi Inhibor Tapioka Terhadap Laju Korosi dan Perilaku Aktif Pasif Stainless stell AISI 304 dalam Media Air Laut Buatan. Jurnal Penelitian Ilmu Teknik 2010;8(2):1-11.

8. Aryani I. Perbandingan Tingkat Ketahanan Korosi Beberapa Braket Stainless steel ditinjau dari Lepasan Ion Ni dan Cr. Jakarta: Universitas Indonesia; 2012.

9. Susana TL, Suci, Djawadi. Distribusi oksigen terlarut dan derajat keasaman $(\mathrm{pH})$ di perairan Selat Sunda. Pesisir dan pantai Indonesia I Tahun 2001. Puslit Oseanografi LIPI. 2001; p.1725.

10.Fontana MG. Corrosion Engineering. Perry's Chemical. Singapore: 1987; p. 47-9.

11.Effendi $\mathbf{H}$. Telaah kualitas air bagi pengelolaan sumber daya dan lingkungan perairan. Yogyakarta: Kanisius, 2003; p.135.

12.Agaoglu G, Arun T, Isgu B, Yarat A. Nickel and Cromium Levels in the Saliva and Serum of Patients with Fix Orthodontic Appliance. Angel Orthod 2001;71(5):375-9. 